\title{
Rainwater Quality Assessment of Different Locations of Dhaka City
}

\author{
Md. Sazzadul Haque ${ }^{1}$, Fatema Naznin Rinkey ${ }^{2}$ \\ ${ }^{1,2}$ Department of Civil \& Environmental Engineering, North South University, Dhaka-1229, Bangladesh
}

\begin{abstract}
Since rainwater harvesting system was assessed to be potential in residential, industrial, educational and other institutions so the study was focused on the rainwater quality of samples collected from rooftop surface runoff of different locations of Dhaka city which is the $2^{\text {nd }}$ most polluted city of the world. Locations were based upon residential, commercial, industrial zone within the area, motorized vehicles use, population, construction works etc. The rooftops were taken mainly of concrete made rooftops and within a single area 03 locations were chosen and a sample of rainwater was collected from a tin made rooftop within that area. The main purpose of this assessment was to compare the rainwater quality of different locations with the drinking water quality standards of Bangladesh and World Health Organization (WHO) in order to observe whether the water needs of further treatment or not for potable use. The samples were checked of physical (Turbidity) and chemical (pH, Electric Conductivity, Total Dissolved Solids, Nitrate, Nitrite, Sulfate, Chloride \& Fluoride) characteristics of water quality. In terms of $\mathrm{pH}$, Nitrate and Fluoride values, there were significant imbalance with the standards and thus required treatment for potable use. And other parameters were within the standards.
\end{abstract}

Keywords: Rainwater Harvesting System, rooftop surface runoff, fluoride, potable

\section{Introduction}

Throughout the history, rainwater harvesting system is used as potable water, irrigation and livestock supply, recharging groundwater and it is also beneficial for reducing runoff and waterlogging problem during the monsoon. [10]

The water supply to the Dhaka city dwellers through ground source is observed as an alarming rate of declination scenario. According to the Institute of Water Modelling (IWM), the water table has plunged by 50 meters in the past four decades. The closest groundwater is now at a depth of over 60 meters in many parts of the city. The average groundwater level in Dhaka city was $11.3 \mathrm{~m}$ in $1970 \mathrm{~s}, 26.6 \mathrm{~m}$ in $1996,28.15 \mathrm{~m}$ in $1997,30.45 \mathrm{~m}$ in $1998,31.85 \mathrm{~m}$ in 1999 and $34.18 \mathrm{~m}$ in 2000. [2] A continuous significant rate of groundwater depletion is noticed.

Various institutions, national and international nongovernmental organizations (NGOs) etc. are promoting, organizing training programs and workshops, consulting and implementing Rainwater Harvesting System (RWHS) around the rural and urban areas of Bangladesh as a reintroduction to an old method. Village Education Resource Centre (VERC), a national nongovernmental organization (NGO) working for women and children, has installed a rainwater harvesting system in its head office for supplying water to the training center and the head office. [6]

Educational institutions like Independent University of Bangladesh (IUB) and University of Information, Technology \& Science (UITS) have implemented rainwater harvesting system (RWHS) as a means for artificial groundwater recharge method. With a capacity of 2000 liter in eight PVC tanks, a rainwater harvesting system is operating at Public Works Department (PWD) head office; a government organization. [6] This demonstrates that rainwater harvesting system is now on effect throughout the commercial, institutional sectors and also some individual industrial sectors of Dhaka city. [1]

The $2^{\text {nd }}$ most polluted city of the world, Dhaka is congested with immense number of population, motorized vehicles, construction sites, garments factories, brick kilns etc. The US air quality index (AQI) developed by Environmental Protection Agency (EPA), Dhaka scored 238 on 21 March, 218 on 22 March in the year 2018 in terms of air quality index (AQI) and resulted as "very unhealthy". [12]

The present study was performed on rainwater collected from different locations of Dhaka city from rooftop surface runoff in order to assess the quality of rainwater in terms of drinking water quality parameters set by Government of Bangladesh (GoB) and World Health Organization (WHO). The study takes into account of potential of rainwater in terms of using as potable (i.e. drinking, cooking etc.) and non-potable (i.e. irrigation, vehicle washing etc.) use and thus performs the tests on various parameters of water in order to observe the quality and further need of any treatment process for use of rainwater.

\section{Study Area}

The locations selected for this study were based upon residential, commercial, industrial sectors, usage of motorized vehicles, construction sites etc. The following figure bellow is the location of the study areas from where the rainwater of roof surface runoff was collected. 


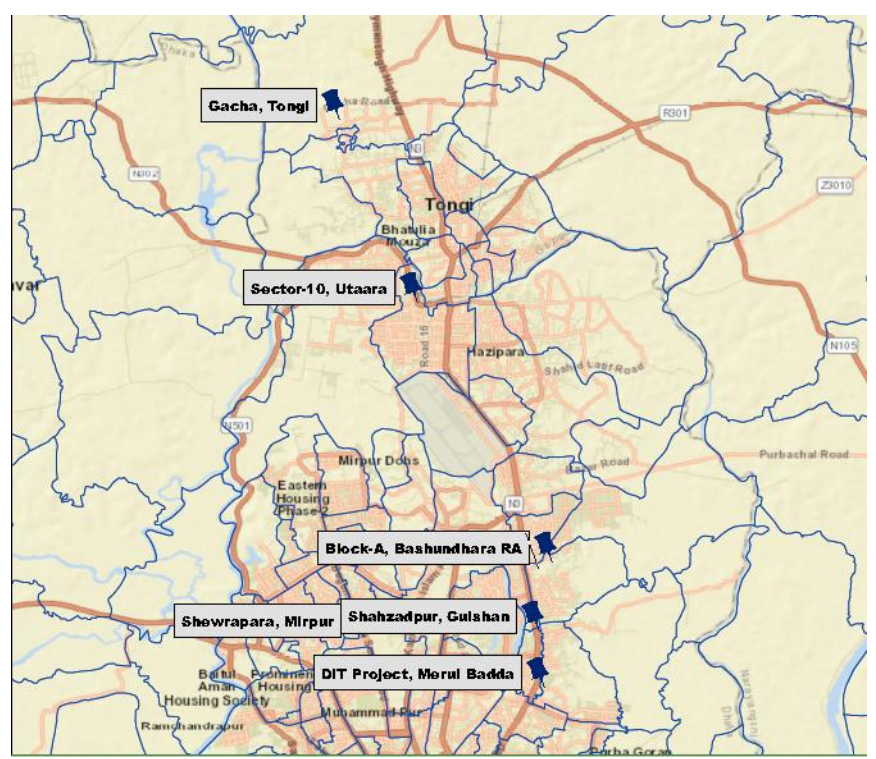

\section{Methodology}

The rainwater samples were collected from rooftop surface runoff of selected areas location. The water was collected from Uttara, Mirpur, Merul Badda, Gulshan, Tongi and 03 locations of Bashundhara Residential Area in where both the concrete and tin made rooftops were selected. In the year 2018, during October-November the rainwater was collected from selected study areas.

Figure 1: The Location of Study Areas

Table 1: Rainwater quality parameters test result

\begin{tabular}{|c|c|c|c|c|c|c|c|c|c|}
\hline & $\begin{array}{c}\text { Turbidity, } \\
\mathrm{NTU}\end{array}$ & $\mathrm{pH}$ & $\begin{array}{c}\text { Electric } \\
\text { Conductivity, } \mu \mathrm{s}\end{array}$ & $\begin{array}{c}\mathrm{TDS}, \\
\mathrm{mg} / \mathrm{L}\end{array}$ & $\begin{array}{c}\text { Nitrate, } \\
\mathrm{mg} / \mathrm{L}\end{array}$ & $\begin{array}{c}\text { Nitrite, } \\
\mathrm{mg} / \mathrm{L}\end{array}$ & $\begin{array}{c}\text { Sulfate, } \\
\mathrm{mg} / \mathrm{L}\end{array}$ & $\begin{array}{c}\text { Chloride, } \\
\mathrm{mg} / \mathrm{L}\end{array}$ & $\begin{array}{c}\text { Fluoride, } \\
\mathrm{mg} / \mathrm{L}\end{array}$ \\
\hline Bangladesh Standards,[4] & 10 & $6.5-8.5$ & - & 1000 & 10 & $<1$ & 400 & $150-600$ & 1 \\
\hline WHO Guidelines,[13] & - & - & - & - & $50\left(\mathrm{as} \mathrm{NO}_{3}^{-}\right)$ & $3\left(\mathrm{as} \mathrm{NO}_{2}{ }^{-}\right)$ & - & - & 1.5 \\
\hline Uttara,(concrete rooftop) & 0.0 & 6.68 & 26.31 & 13.17 & 4.95 & $\mathrm{~N} / \mathrm{A}$ & 4.35 & 0.76 & N/A \\
\hline Mirpur,(concrete rooftop) & 0.0 & 6.44 & 45.0 & 22.5 & 10.35 & N/A & 11.09 & 1.52 & N/A \\
\hline Merul Badda,(concrete rooftop) & 0.0 & 6.75 & 34.0 & 17.1 & 1.04 & N/A & 3.11 & 2.97 & 0.16 \\
\hline Gulshan,(concrete rooftop) & 0.0 & 6.44 & 45 & 22.5 & 1.44 & N/A & 4.80 & 0.52 & 0.40 \\
\hline Tongi, (concrete rooftop) & 0.0 & 6.63 & 436 & 218 & 1.87 & N/A & 4.42 & 1.25 & 2.27 \\
\hline $\begin{array}{c}\text { Bashundhara R/A: Sample } \\
\text { 01,(concrete rooftop) }\end{array}$ & 0.0 & 6.48 & 195 & 97.2 & 14.42 & N/A & 19.56 & 3.53 & 0.82 \\
\hline $\begin{array}{c}\text { Bashundhara R/A: Sample } \\
\text { 02,(concrete rooftop) }\end{array}$ & 0.0 & 6.37 & 154.1 & 77.1 & N/A & N/A & 2.80 & 12.63 & 1.93 \\
\hline $\begin{array}{c}\text { Bashundhara R/A: Sample 03,(tin } \\
\text { rooftop) }\end{array}$ & 0.0 & 6.69 & 430 & 216 & N/A & N/A & 2.16 & 9.31 & 1.44 \\
\hline
\end{tabular}

The rainwater from rooftop surface runoff was collected into plastic pots and after a First Flush period of 15 minutes. Usually a 10 minute First flush period is practiced and an additional 5-minute period was performed in order to wash off the rooftop from dust, debris, excrement of birds etc.

The parameters checked of the samples collected from selected areas are $\mathrm{pH}$, Turbidity, Total Dissolved Solids (TDS), Electric Conductivity (EC), Fluoride, Chloride, Nitrite, Nitrate and Sulfate. All tests were performed in the "Environmental Chemistry Laboratory" of North South University.

The machines incorporated in order to test Turbidity was 'Lutron TU 2016', for pH 'Hanna HI 221', for Total dissolved solids (TDS), Electric Conductivity (EC) 'Hanna HI 2300' and for the ions 'Dionex ICS 1600', ion chromatography system.

\section{Result and Data Analysis}

The following Table 1 provided below contains the data of water quality parameters of rainwater samples collected from roof surface runoff of Uttara, Mirpur, Merul Badda, Tongi, Gulshan and Bashundhara Residential area in where three water samples were collected from both concrete and tin made rooftop. The values are then compared with the Bangladesh Standards and the standards of World Health Organization (WHO).

$p H$ : Rainwater is a bit acidic since it falls through the atmospheric concentration of Carbon dioxide, emission of gases from motor vehicles and it also get changed in the contact with the rooftop where it gets mixed with different chemical elements of rooftop, leaves, dust and bird dung. These depositions of particulates mainly contributed in the change of $\mathrm{pH}$ values. [9] On the other hand, low $\mathrm{pH}$ value than the standard range can cause bad effect to the user like corrosion of steel during vehicle wash and also it is not good to use for irrigation purpose. [5] $\mathrm{pH}$ is the most important indicative water quality parameter for operational management and it determines the effectiveness of the treatment. [11] From Figure 2, the highest value of $\mathrm{pH}$ is 6.75 from the sample of Merul Badda. And the samples from Mirpur, Gulshan and Bashundhara Residential area: Sample 2, are less than the Bangladesh Standards, 6.44, 6.44 and 6.37 respectively. 


\section{International Journal of Science and Research (IJSR) \\ ISSN: 2319-7064}

Impact Factor (2018): 7.426

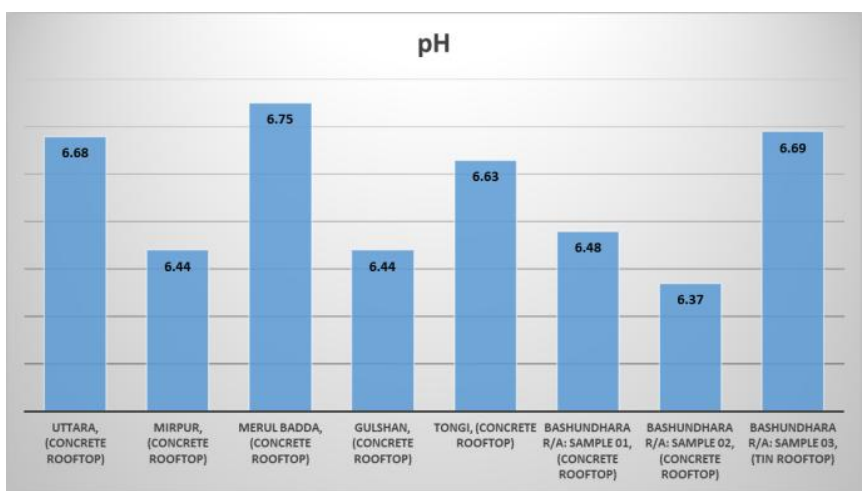

Figure 2: $\mathrm{pH}$ value of collected samples from roof surface runoff

Fluoride: Fluoride is toxic to humans and other animals with large quantities but small concentration can be beneficial. Fluoride is added in drinking water supplies for good dental formation if sufficient amount is not found in nature. Excessive dosages of fluoride can cause bone fluorosis and other skeletal abnormalities. [7] From the Figure 3, $2.27 \mathrm{mg} / \mathrm{L}$ is the highest value from Tongi's sample, which was collected from nearby industrial zone. And the 03 Samples collected from Bashundhara Residential area, a trend of high Fluoride value is observed within and 02 samples value exceeded the limit. The Sample 02 is $1.93 \mathrm{mg} / \mathrm{L}$ which crossed both the Bangladesh and WHO standards and the Sample 03 is $1.44 \mathrm{mg} / \mathrm{L}$ which crossed only the Bangladesh standard.

Total Dissolved Solids (TDS): Many dissolved substances are undesirable in water. Dissolved minerals, gases and organic constituents may produce aesthetically displeasing color, tastes and odors. Some chemicals can be toxic and some of the dissolved organic constituents have been shown to be carcinogenic. [7] In the Figure 4, the highest Total Dissolved Solids value can be found within Tongi, 218 $\mathrm{mg} / \mathrm{L}$ but all the values are within the standards and no potential threat is possessed.

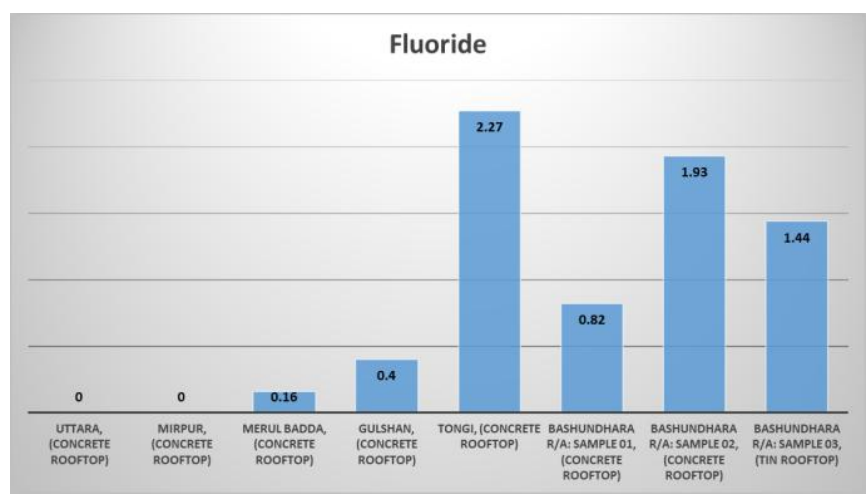

Figure 3: Fluoride value of collected samples from roof surface runoff

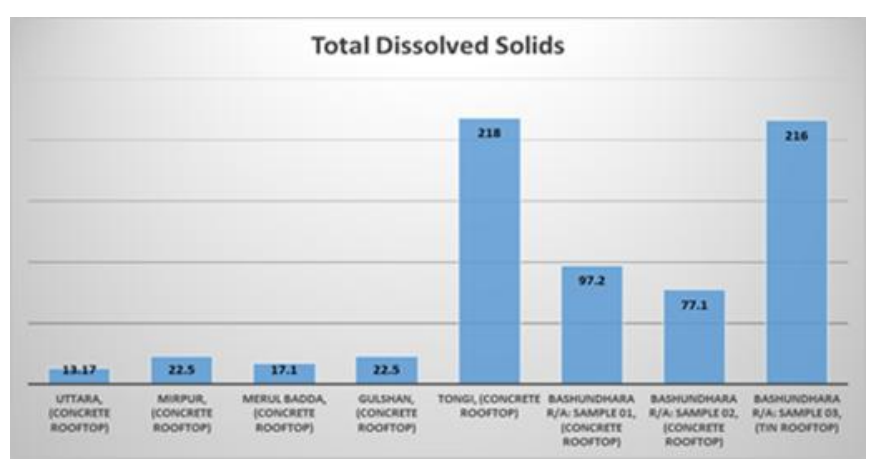

Figure 4: Total Dissolved Solids value of collected samples from roof surface runoff

Nitrate \& Nitrite: Nitrate is known to be the most widespread agriculture contaminant but presence of nitrate/nitrite is considered to have minimal effect on the disease burden. The long term exposure to nitrate/nitrite may increase stomach cancer. A recent study suggested that miscarriage might also be linked to high nitrate levels although scientists have not confirmed this. [11] Methemoglobinemia (infant cyanosis or 'blue baby syndrome') has occurred in infants who have been given water or fed formula with water having high concentrations of nitrate. [3] From Figure 5, in Mirpur and Bashundhara Residential area: Sample 01, have the highest value of 10.35 and 14.42 respectively, which exceeds the Bangladesh Standards. And Nitrite is found to be zero from all the samples of every location.

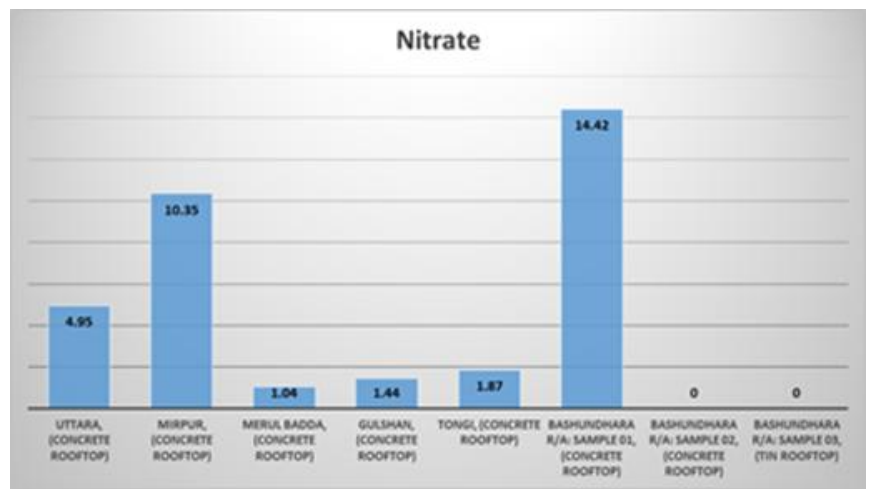

Figure 5: Nitrate value of collected samples from roof surface runoff

Chloride: Some amount of chloride is present within the most of the waters which can be caused by leaching of marine sedimentary deposits or by pollution from sea water, brine or industrial or domestic wastes. Chloride concentrations more than $250 \mathrm{mg} / \mathrm{L}$ may produce a noticeable taste in the drinking water. [3] From Figure 6, the chloride values from the test result show that it is well below the standards. 


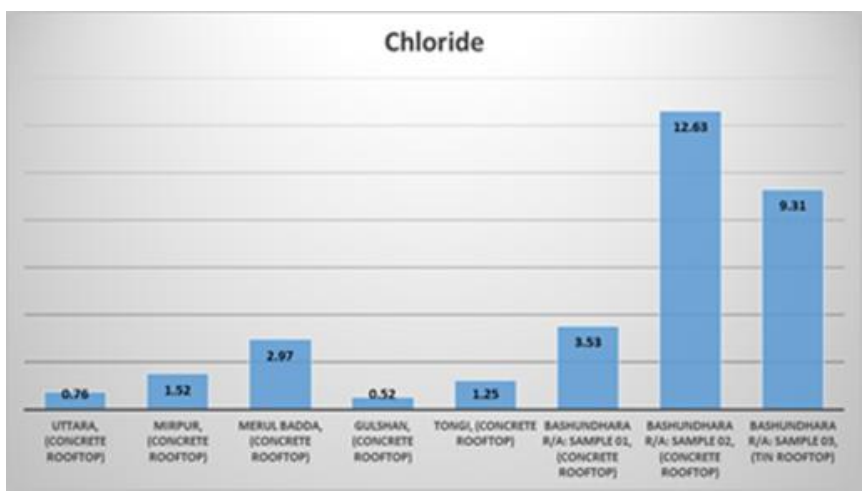

Figure 6: Chloride value of collected samples from roof surface runoff

Sulfate: Water which contains high amount of sulfate may be undesirable because of their laxative effects. [3] From Figure 7 , the sulfate values of the study areas are so insignificant compared to the range set by Government of Bangladesh and World Health Organization (WHO).

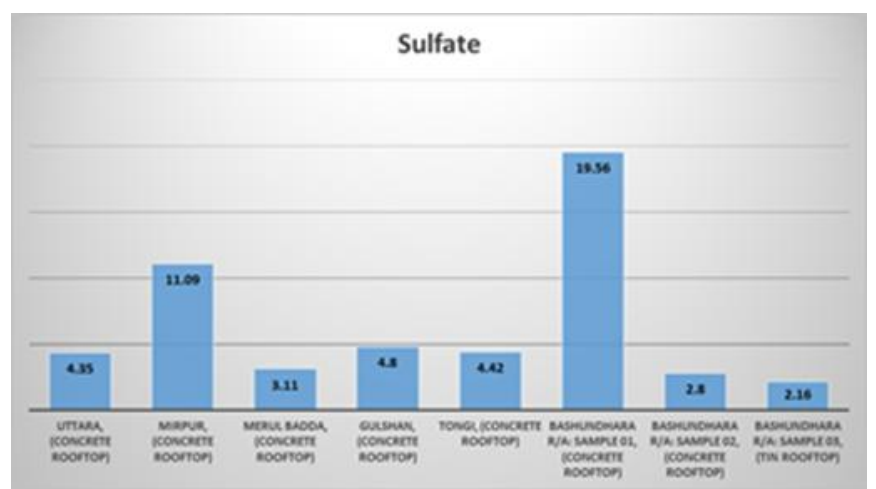

Figure 7: Sulfate value of collected samples from roof surface runoff

Turbidity: Disinfection of turbid waters is difficult because of the adsorptive characteristics of some colloids and because the solids may partially shield organisms from the disinfectant. [7] The value of turbidity is shown to be zero in all the samples collected from the study areas.

\section{Conclusion}

Rainwater is considered to be the pure form of water. The chemical composition of rainwater is influenced by a multitude of factors, such as geographic location and influences, prevailing meteorological conditions and anthropogenic activities (i.e. agriculture, industry, motor vehicle emissions and the like) and thus varies greatly by location, season and even storm type. [8] The test result of samples of rainwater collected from different locations of Dhaka city compared with the drinking water quality standards of Bangladesh and World Health Organization (WHO) observed to be undesirable for using it in potable purposes without treatment. So the necessary steps need to be taken while collecting rainwater from rooftop surface and to use for potable purposes.

\section{Recommendation}

The following study takes into account of the physical and chemical characteristics of the rainwater quality. The following steps need to be examined in further experimentation of rainwater quality analysis,

- The study areas were small compared to the area of Dhaka city. So more study areas need to be assessed for more clarification in the topic of rainwater quality.

- The study was conducted during the middle and the end of the monsoon. An analysis need to be performed during the end of dry season and the beginning of monsoon in order to check if there is any change in rainwater quality parameters.

- The microbiological characteristics and if necessary radiological characteristics of rainwater should be examined in order to assess the water quality parameters.

\section{Acknowledgement}

Dr. Md. Sirajul Islam, Professor, Department of Civil \& Environmental Engineering, North South University, Dhaka-1229, Bangladesh.

Dr. Asif Mohammad Zaman, Associate Professor, Department of Civil \& Environmental Engineering, North South University, Dhaka-1229, Bangladesh.

\section{References}

[1] Alum, M. A. (June, 2013). Promoting rainwater harvesting in industry and urban area: initiatives of RAiN forum. In Rainwater harvesting in Bangladesh: Potentials, challenges and stakeholders' responses (pp. 90-91). Dhaka, Bangladesh: WaterAid Bangladesh.

[2] Das, A. (August, 2016). Dhaka caving in alarmingly as grounwater level falls. Dhaka: The Independent.

[3] Davis, M. L. (2013). General water supply design considerations. In Water and Wastewater Engineering (pp. 2-24). New Delhi: McGraw Hill Education (India) Private Limited.

[4] ECR. (1997). Environmental Conservation Rules. Department of Environment, Ministry of Environment and Forest, Government of the People's Republic of Bangladesh.

[5] Hanim, N. (2015). Analysis Of Rainwater Quality At The Rooftop For Domestic Use Of Flatlet Building K8k, Kolej Ungku Omar. Water Research.

[6] Hasin Jahan, K. R. Hyder (June, 2013). Rainwater harvesting demonstration plants in Dhaka. In Rainwater harvesting in Bangladesh: Potentials, challenges and stakeholders' responses (pp. 83-84). Dhaka, Bangladesh: WaterAid Bangladesh.

[7] Howard S. Peavy, Donald R. Rowe and George Tchobanoglous (1985). Water Quality: Definitions, Characteristics and Perspectives. In Environmental Engineering (pp. 17-37). Singapore: McGraw-Hill International Editions.

[8] ITN-BUET. (March 2016). Water Quality and Treatment. In Prospects, Principles and Practice of Rainwater Harvesting in Bangladesh (p. 32). Dhaka, Bangladesh: WaterAid Bangladesh. 
[9] M.D. Kathy, G.E.V. Giesen and C.A. Novak (2014). Designing rainwater harvesting system: Integrating Rainwater into Building System. Hydrological Research.

[10] M. M. Rahman, S. Afreen and M. A. Hussain (March, 2011). Potential of Rainwater harvesting in Dhaka city. 3rd International Conference on Water \& Flood Management (ICWFM-2011), (pp. 1-11).

[11] RAIN. (July, 2008). RAIN Water Quality Guidelines: Guidelines and practical tools on rainwater quality, (version 1). Rain Foundation.

[12] Respro Bulletin Board. (2018, 22 $2^{\text {nd }}$ March, Thursday). Retrieved from: www.respromasks.com/2018/03/22/dhaka-maintains-itsrank-as-2nd-most-polluted-city-in-the-world- accessed on 10:00pm; $25^{\text {th }}$ January, 2019.

[13] WHO. (2011). Guidelines for Drinking Water Quality (4th Edition) . Geneva, Switzerland: World Health Organization.

\section{Author Profile}

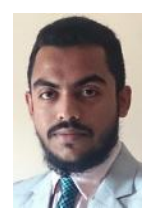

Md. Sazzadul Haque is the final year student of the Civil \& Environmental Engineering Department of North South University. He has received training on Urban Rainwater Harvesting System from workshop arranged by WaterAid Bangladesh and RAiN Forum. Currently he is researching on organic solid waste management for Dhaka city.

Fatema Naznin Rinkey has completed BSc in Civil \& Environmental Engineering from North South University. She is currently pursuing for MSc in Environmental Engineering and research interest in Environmental pollution related topics. 